УДК 624.131

\title{
ОПЫТ ИНЖЕНЕРНО-ГЕОЛОГИЧЕСКОГО РАЙОНИРОВАНИЯ ПО НЕСУЩЕЙ СПОСОБНОСТИ ГРУНТОВ ПРОМПЛОЩАДКИ ЭЛЬГИНСКОГО ГОРНО-ОБОГАТИТЕЛЬНОГО КОМБИНАТА В ЯКУТИИ
}

\section{Строкова Людмила Александровна',} sla@tpu.ru

\author{
Дмитриева София Алексеевна', \\ dmitrieva_sa93@mail.ru \\ Осьмушкина Наталья Викторовна², \\ yjtisiz@nery.sakha.ru

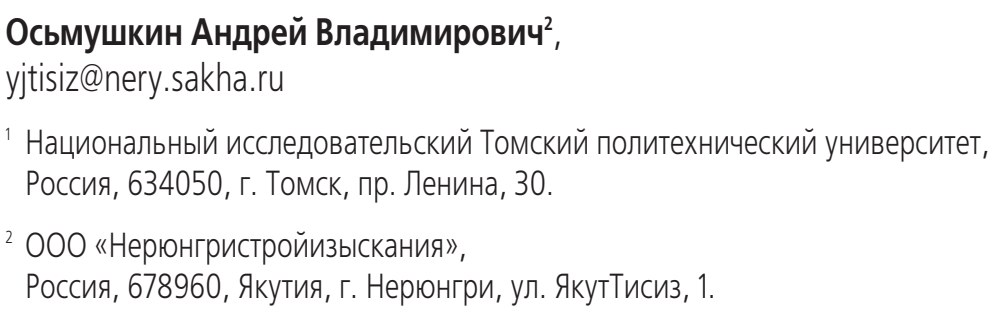

Актуальность исследования обусловлена стремительным ростом геологоразведочной и производственной деятельности в районах вечной мерзлоты в России за последние сорок лет. В статье приведена характеристика грунтов промплощадки Эльгинского горно-обогатительного комбината в Республике Саха (Якутия) по несущей способности. Инженерно-геологическая оценка территории необходима для того, чтобы поддержать процесс принятия решений по размещению сооружений, а также для того, чтобы строительство объектов осуществлялось с меньшим отрицательным воздействием на окружающую среду, сопровождалось снижением опасности и ущерба как для строительства, так и в целом для общества и экономики.

Целью данного исследования является описание инженерно-геологических и гидрогеологических условий промплощадки, экзогенных геологических процессов, которые могут быть актуальны для установления пригодности территории к застройке.

Объектом исследования является геологическая среда промплощадки горно-обогатительного комбината. Рассмотрены основные природные компоненты, влияющие на планирование и развитие землепользования: литологический состав; геоморфологические и тектонические условия; физико-механические свойства пород, гидрологические и мерзлотно-гидрогеологические условия района. Методы. Данное исследование включает в себя краткий обзор соответствующей литературы; анализ информации, полученной из фондов изыскательской компании, определение признаков и методики районирования. Все информационные слои о природной среде обрабатывались, затем объединялись для получения единой инженерно-геологической карты.

Результаты. Разработана карта инженерно-геологического районирования по несущей способности. На карте выделены три категории районов с разной степенью благоприятности грунтов исследуемой территории для строительства объектов, такие как благоприятные, приемлемые и неблагоприятные условия.

\section{Ключевые слова:}

Горно-обогатительный комбинат, карьерная добыча, грунт, уголь, геологический процесс, физико-механические свойства, несущая способность, районирование.

\section{Введение}

Стремительный рост геологоразведочной и производственной деятельности в районах вечной мерзлоты в России повысил значимость инженерно-геологической оценки этих территорий. В работах уральской школы инженеров-геологов [1-3] уделено внимание описанию инженерно-геологических условий месторождений твердых полезных ископаемых Урала и сопредельных областей.

Работы томской школы инженеров-геологов [4-8] посвящены изучению закономерностей формирования инженерно-геологических условий угольных месторождений Сибири и Дальнего Востока, оценке устойчивости бортов угольных карьеров в Кузбассе и Восточной Сибири.

Многочисленные исследования направлены на изучение влияния горных работ на поверхностные и подземные воды [9-13], оценку состояния окружающей среды с помощью ГИС-технологий [14-16].
В течении последних десяти лет появились работы по исследованию Эльгинского угольного месторождения. Так, в работах [17-19] выполнена оценка трещиноватости коренных пород до глубины 250 м, их физико-механических свойств, устойчивости в бортах карьеров. Е.А. Хоютанов оценивает зольность углей Эльгинского месторождения [19]. Оценка факторов техногенного воздействия на природную среду района (поверхностные воды, атмосферу) рассмотрена в работах [20, 21].

Технология инженерно-геологического районирования подробно изложена в работах [22-27]. Этот метод позволяет решать много задач по планированию землепользования, поэтому давно и широко используется в мире.

Целью данного исследования является описание инженерно-геологических и гидрогеологических условий промплощадки, экзогенных геологических процессов, которые могут быть актуальны 
для установления пригодности территории к застройке. Для этого необходимо рассмотреть основные природные компоненты геологической среды, влияющие на планирование и развитие землепользования: литология; топография; сейсмотектоника; геотехника; гидрология, гидрогеология и вечная мерзлота.

\section{Характеристика инженерно-геологических условий}

Территория Эльгинского месторождения в инженерно-геологическом отношении изучена довольно подробно в последние годы [28-30].

По административному делению район работ расположен в Нерюнгринском районе Республики Саха (Якутия), в 400 км от г. Нерюнгри на восток. В районе проектируемых работ постоянно живущее население отсутствует. Единственным населенным пунктом является поселок Эльга - бывшая база Эльгинской геологоразведочной партии.

Площадь расположена на юго-восточной окраине Алданского нагорья, в пределах Токинской впадины, являющейся составной частью ЮжноЯкутского каменноугольного бассейна. Токинская впадина ограничена с юга Становым, а с севера Учуро-Идюмским хребтами. Непосредственными границами Эльгинского месторождения являются: восточной - р. Укикит, южной - крупноамплитудное нарушение северо-западного простирания, западной - р. Ундыткан, северной - условная линия, соединяющая р. Ундыткан с р. Эльга в среднем их течении.

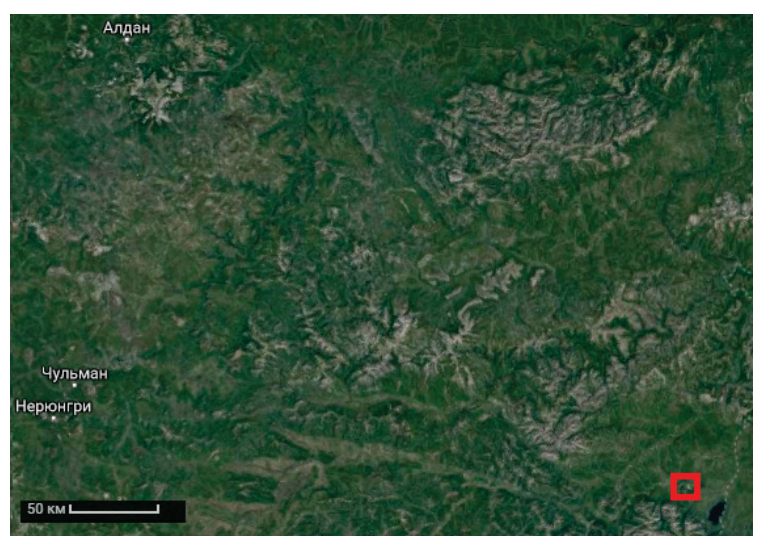

Рис. 1. Местоположение изучаелой площадки

Fig. 1. Location of the study area

В геолорфологическол отношении промплощадка расположена в долинах реки Укикит и ее правого притока ручья Безымянный, на склонах различной крутизны пологоступенчатого водораздела. Отметки поверхности колеблются от 936 до 1029 м, перепад высот составляет 93 м.

Микрорельеф ровный, мелкобугристый и бугристый, осложнен ложбинами округлой и вытянутой формы, а также наличием на поверхности задернованных или открытых выходов песчаника. Растительность представлена редким лиственничным лесом, редким кедровым стлаником, сменяю- щимся густым на склонах средней крутизны и крутых. Отмечаются «пятна» березняка, повсеместно - багульник, голубичник. В долине - тальник и ерник. Покров в основном моховой, мохово-брусничный, мохово-травяной.

В геологическол строении площадки принимают участие верхнеюрские отложения нерюнгриканской свиты $\left(\mathrm{J}_{3} \mathrm{nr}\right)$, перекрытые с поверхности верхнечетвертичными и современными отложениями озерно-болотного (lbQ $\left(\mathrm{aQ}_{\mathrm{III-IV}}\right)$ и элювиально-делювиального $\left(\mathrm{edQ}_{\mathrm{III-IV}}\right)$ генезисов [29,30].

Верхнечетвертичные и современные отложения озерно-болотного генезиса ( $\left.l b Q_{I I I-I V}\right)$ имеют повсеместное распространение по площади, с мощностью до 0,4...1,8 м. Отложения представлены слабо-, среднезаторфованными песками пылеватыми, супесями и суглинками с дресвой, дресвяными, дресвяными и щебенистыми грунтами с песчаным, супесчаным и суглинистым заполнителем, а также торфом бурым среднеразложившимся.

Верхнечетвертичные и совреленные отложения аллювиального генезиса $\left(a Q_{\text {III-IV }}\right)$ имеют ограниченное распространение по площади, вскрыты только в долине ручья Безымянный под почвеннорастительным слоем и элювиально-делювиальными отложениями. Отложения представлены песками, супесью и суглинками с гравием, гравелистыми, галечниковыми и гравийными грунтами с песчаным, супесчаным и суглинистым заполнителем, мощностью 0,5...10,2 м. Обломочный материал представлен осадочными, магматическими и метаморфическими породами, плохой, средней и хорошей степени окатанности.

Верхнечетвертичные и современные отложения элювиально-делювиального генезиса (еdQ $Q_{\text {III-IV }}$ ) имеют повсеместное распространение по площади, вскрыты с поверхности мощностью $0,9 . . .3,7$ м. Отложения представлены песками пылеватыми, супесями и суглинками с дресвой, дресвяными, а также дресвяными и щебенистыми грунтами с песчаным, супесчаным и суглинистым заполнителем от 10 до $49 \%$. Обломочный материал представлен осадочными породами, различной прочности.

Верхнеюрские отложения нерюнгриканской свиmы $\left(J_{3} n r\right)$ имеют повсеместное распространение, залегают под четвертичными отложениями с глубины $0,5 . .4$ м, вскрытой мощностью 0,5...55,0 м. Породы представлены песчаниками и алевролитами различной прочности с пластами и пропластками углей.

В геокриологическол отношении площадка расположена в зоне сплошного развития многолетнемерзлых пород. Грунты слоя сезонного оттаивания в интервале $0,0 \ldots 4,0$ м находились как в талом, так и в мерзлом состоянии в период полевых работ с апреля по декабрь [30]. Грунты имеют массивную и слоистую криогенную текстуру, при оттаивании: глинистые грунты твердые до текучих, крупнообломочные и песчаные грунты от малой степени водонасыщения до водонасыщенных. 
Скальные грунты - в морозном состоянии. Глубина сезонного оттаивания зависит от многих факторов (летняя температура воздуха, растительный и моховой покров, влажность и литологический состав грунтов зоны аэрации и т. п.). На глубине годовых нулевых амплитуд температура изменяется от минус 0,1 до минус $1,5^{\circ} \mathrm{C}$. Нормативная глубина сезонного оттаивания составляет четыре метра.

Гидрогеологические условия площадки характеризуются развитием надмерзлотных грунтовых вод, вскрытых в трех шурфах на глубине 1 ...2 м. Водовмещающими грунтами являются щебенистые, галечниковые грунты с супесчаным заполнителем и алевролиты «рухляки». Питание грунтовых вод происходит в основном за счёт инфильтрации атмосферных осадков и оттаивания сезонно-мёрзлых грунтов, водоупором служат вечномерзлые грунты. С прекращением питания атмосферными осадками, наступлением отрицательных температур воздуха, перемерзанием русел водотоков надмерзлотный водоносный горизонт истощается, сокращается и к весне в основном прекращает свое существование. В местах отсутствия плотных мерзлых пород вода по трещинам свободно фильтруется вниз, пополняя запасы нижележащего комплекса пород.

По химическому составу вода гидрокарбонатная-натриевая-кальциевая, гидрокарбонатнаянатриевая и гидрокарбонатная-кальциевая-натриевая с общей минерализацией 126,66...262,96 мг/л, неагрессивная к бетону, слабоагрессивная к железобетонным конструкциям. Коррозионная активность грунтовых вод по отношению к алюминиевой оболочке кабеля средняя, к свинцу - низкая, средняя и высокая [30].

Геологические процессы и явления. Из неблагоприятных процессов и явлений, негативно влияющих на строительство и эксплуатацию сооружений, следует отметить поверхностное заболачивание площадки, морозное выпучивание каменного материала на водораздельных площадках и склонах, морозное пучение рыхлых грунтов при промерзании и наличие в разрезе ослабленных зон по углям, алевролитам и песчаникам «рухлякам» [29].

Пучение грунтов чаще всего отмечается в нижних частях склонов и днищ долин, сложенных тонкодисперсными грунтами. В зоне сезонного оттаивания-промерзания в интервале глубин $0 . . .2,5$ м заторфованные грунты и торф обладают морозной пучинистостью сильной степени.

Курулы. Наиболее широко развиты на пологих склонах. Глыбы размером от 0,2 до 1,0 м открытые или покрыты сверху лишайником. Поражённость территории каменными потоками составляет $5 \%$. Следует учесть, что курумы являются наиболее опасным из геологических процессов, так как при проведении взрывных работ или подрезки его траншеями возможны подвижки каменных потоков.

Заболачивание развивается в пойме Безымянного ручья и на пологих склонах. Заболачивание преимущественно слабое. Питание происходит за счёт атмосферных осадков и надмерзлотных вод. Торф чаще слаборазложившийся, в целом заболоченные участки занимают значительную часть площадки.

Состав и свойства грунтов. В 2009-2010 гг. на площадке пробурено 230 скважин глубиной до $3 . .60$ м с отбором проб грунтов для определения физико-механических свойств В результате статистической обработки данных о геологическом строении участка, литологических особенностях грунтов, в пределах промплощадки выделено 2 слоя и 27 инженерно-геологических элементов (ИГЭ)[29, 30].

В связи с тем, что некоторые грунты находятся в идентичных условиях, имеют близкие показатели физико-механических свойств, они объединены в один инженерно-геологический элемент, напримep:

- песок пылеватый, суглинок с дресвой, супесь с дресвой и супесь слабо-, среднезаторфованные - в ИГЭ-2 (суглинок заторфованный);

- супесь и суглинок дресвяные, супесь и суглинок гравелистые, с включением гравия, дресвяный и щебенистый грунт с песчаным, супесчаным и суглинистым заполнителем слабо-, среднезаторфованные - в ИГЭ-3 (заторфованный грунт);

- дресвяный грунт с песчаным, суглинистым заполнителем и щебенистые грунты с песчаным, супесчаным и суглинистым заполнителем - в ИГЭ-7 (дресвяный грунт с супесчаным заполнителем);

- гравийный грунт с песчаным и супесчаным заполнителем - в ИГЭ-13 (галечниковый грунт с супесчаным заполнителем) [30].

Нормативные показатели физико-механических свойств выделенных ИГЭ приведены в табл. 1 , 2. Грунты не засолены, обладают средней и низкой степенью коррозионной активности по отношению к стали, средней и высокой - к свинцу и высокой - к алюминиевой оболочке.

Слой 1 Почвенно-растительный в отдельный элемент не выделен ввиду маломощности $(0,1 . .0,4$ м). При производстве работ он подлежит полному удалению с последующим использованием для целей рекультивации земель.

Слой 2 Лед мутный, мутно-коричневый с песком. Вскрыт локально скважинами № 64, 65, 73, 218 с глубины $0,8 \ldots 2,4$ м, мощностью $0,8 \ldots 3,6$ м. В отдельный элемент не выделен ввиду того, что при производстве работ он подлежит полному удалению из работы оснований зданий и сооружений.

ИГЭ-1 Торф буро-коричневый, бурый, коричневый, имеет ограниченное распространение по площади, вскрыт с поверхности, с мощностью $0,3 . .1,2$ м. При промерзании грунт обладает пучинистыми свойствами.

ИГЭ-2 Суглинок заторфованный бурый, коричневый, серо-коричневый, темно-серый, с включениями дресвы песчаников до $2 . . .23 \%$, имеет ло- 


\begin{tabular}{|c|c|c|c|c|c|c|c|c|c|c|c|c|c|c|c|c|c|c|c|c|}
\hline 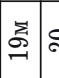 & $\stackrel{8}{\circ}$ & ${ }_{0}^{8}$ & 1 & $\Rightarrow$ & : & 1 & 1 & & & 总 & $\underset{\mathscr{G}}{\mathscr{G}}$ & $\rightarrow$ & & 跑 & 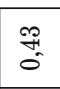 & 1 & I & $\ddot{N}$ & $\grave{\Lambda}$ & \\
\hline$\Rightarrow$ & $\therefore$ & $\overrightarrow{0}$ & 1 & 7 & $\begin{array}{l}\overrightarrow{0} \\
0\end{array}$ & 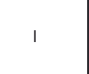 & I & & & E & 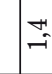 & $\stackrel{\stackrel{\circ}{\leftrightarrows}}{\rightarrow}$ & & {$\left[\begin{array}{l}\infty \\
0 \\
0 \\
0\end{array}\right.$} & I্ & 1 & 1 & ন্ড & $\grave{\Lambda}$ & \\
\hline 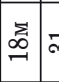 & $\vec{\infty}$ & $\overrightarrow{0}$ & 气̊ & $\begin{array}{l}* \\
0\end{array}$ & $\stackrel{8}{\circ}$ & $\begin{array}{l}\infty \\
\infty \\
0 \\
0\end{array}$ & $\begin{array}{l}\text { 今̀ } \\
\text { o }\end{array}$ & 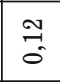 & $\overbrace{i}^{\infty}$ & o. & \& & 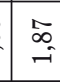 & $\mid \begin{array}{l}2 \pi \\
0 \\
0\end{array}$ & $\begin{array}{l}7 \\
0\end{array}$ & \begin{tabular}{l}
$\tilde{Z}$ \\
\hdashline \\
\hdashline
\end{tabular} & I & 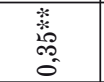 & 蒡 & 离 & \\
\hline$\stackrel{=}{\infty}$ & $\Rightarrow \frac{10}{0}$ & 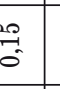 & \begin{tabular}{l}
$\mathscr{0}$ \\
\multirow{0}{0}{} \\
0
\end{tabular} & $\begin{array}{l}\infty \\
0 \\
0\end{array}$ & : & $\begin{array}{l}\infty \\
\infty \\
0 \\
0\end{array}$ & 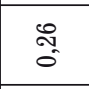 & $\Rightarrow$ & P & 党 & $\underset{\substack{0 \\
\sim}}{\stackrel{\infty}{i}}$ & $\stackrel{\infty}{\infty}$ & 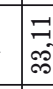 & 10 & $\stackrel{\infty}{\infty}$ & I & 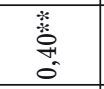 & 霜 & * & \\
\hline$\underset{\Xi}{\Xi}$ & $\underset{\overbrace{}}{\mathscr{\Xi}}$ & $\Rightarrow$ & :̊ & 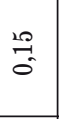 & 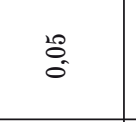 & స్ & $\begin{array}{l}\overrightarrow{\text { gे }} \\
\mathrm{o}\end{array}$ & $\begin{array}{l}: \\
0 \\
0\end{array}$ & $\vec{\wedge}$ & 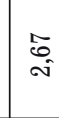 & $\vec{a}$ & $\stackrel{\rightarrow}{\rightarrow}$ & 足 & $=$ & $\hat{\circ}$ & 1 & $\begin{array}{l}\text { 类 } \\
\text { in } \\
0 \\
0 \\
0\end{array}$ & 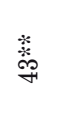 & 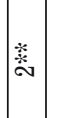 & 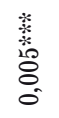 \\
\hline$\approx \approx$ & $\stackrel{\bar{c}}{*}$ & $\Rightarrow$ & $\stackrel{\infty}{\circ}$ & 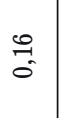 & :ै & \begin{tabular}{l}
$\infty$ \\
\hdashline \\
\hdashline \\
0
\end{tabular} & $\begin{array}{l}\overrightarrow{\text { gे }} \\
\mathrm{o}\end{array}$ & $\begin{array}{l}8 \\
0 \\
0\end{array}$ & $\stackrel{\ominus}{v}$ & $\vec{\sigma}$ & 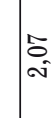 & $\stackrel{\infty}{\stackrel{\infty}{\rightarrow}}$ & & 18 & $\stackrel{\infty}{\circ}$ & 1 & $\begin{array}{l}\text { 蒡 } \\
\text { 晋 }\end{array}$ & 类 & 产 & 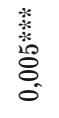 \\
\hline$\sum_{\exists}^{Z}$ & 9 & $\begin{array}{l}\text { I0 } \\
0 \\
0\end{array}$ & 1 & ב̊ & : & 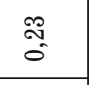 & $\stackrel{7}{0}$ & 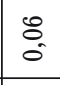 & I & $\begin{array}{l}\mathscr{O} \\
\stackrel{\leftrightarrow}{\circ}\end{array}$ & $\vec{a}$ & 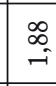 & 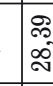 & s. & - & 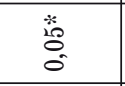 & $\begin{array}{l}\text { 惫 } \\
0 \\
0\end{array}$ & 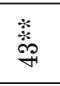 & $\stackrel{*}{*}$ & \\
\hline$\exists=$ & $\circ$ & ? & 1 & $\begin{array}{l}\text { đ̃. } \\
\text { o. }\end{array}$ & $\begin{array}{l}\text { to } \\
\text { o }\end{array}$ & $\begin{array}{l}\text { đ̃ } \\
\text { o. }\end{array}$ & $\stackrel{0}{0}$ & $\stackrel{0}{\circ}$ & 1 & $\begin{array}{l}: \\
\stackrel{0}{0}\end{array}$ & $\stackrel{\rho}{\stackrel{\sim}{\sim}}$ & $\stackrel{20}{9}$ & & 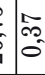 & $\begin{array}{l}\mathbb{8} \\
\text { Oे }\end{array}$ & 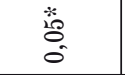 & 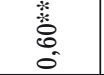 & 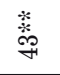 & $\stackrel{*}{*}$ & \\
\hline 㤐: & $\Rightarrow$ & $\begin{aligned} \overrightarrow{7} \\
0\end{aligned}$ & : & $\stackrel{9}{\circ}$ & $\begin{array}{l}0 \\
0 \\
0\end{array}$ & స્નિ & $\stackrel{0}{0}$ & 告 & $\vec{\wedge}$ & $\begin{array}{l}18 \\
\stackrel{1}{0} \\
i\end{array}$ & $\underset{\sim}{\approx}$ & $\stackrel{\circ}{-}$ & $\mid \begin{array}{l}\infty \\
\dot{m} \\
\dot{m}\end{array}$ & $\begin{array}{l}8 \\
0 \\
0\end{array}$ & \begin{tabular}{|l}
18 \\
18 \\
0 \\
0
\end{tabular} & $\begin{array}{l}\text { 蒿 } \\
0 \\
0\end{array}$ & 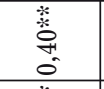 & 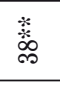 & 1 & \\
\hline$\approx=$ & $\Rightarrow$ & $\begin{array}{l}\Delta \\
0 \\
0\end{array}$ & $\begin{array}{l}\text { స̃. } \\
\text { o. }\end{array}$ & 芯 & $\begin{array}{l}28 \\
0 \\
0\end{array}$ & $\begin{array}{l}\text { đ̃ } \\
\text { Oे }\end{array}$ & $\stackrel{7}{0}$ & $\begin{array}{l}28 \\
0 \\
0\end{array}$ & त & $\begin{array}{l} \\
i \\
i\end{array}$ & 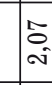 & $\stackrel{8}{8}$ & & {$\left[\begin{array}{l}\infty \\
\infty \\
0 \\
0\end{array}\right.$} & $\begin{array}{l}8 \\
:-\end{array}$ & 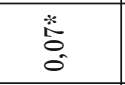 & $\begin{array}{l}\text { 絭 } \\
\text { 尊 } \\
0\end{array}$ & 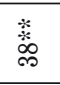 & 1 & \\
\hline 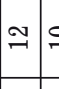 & $\circ$ & 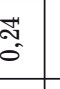 & : & ?ै & $\begin{array}{l}10 \\
0 \\
0\end{array}$ & 1 & I & 1 & I & $\begin{array}{l}\stackrel{\tilde{o}}{\sigma} \\
\stackrel{\sim}{*}\end{array}$ & $\mathscr{I}$ & $\stackrel{\mathrm{F}}{\mathrm{F}}$ & & {$\left[\begin{array}{l}\infty \\
\infty \\
0\end{array}\right.$} & $\begin{array}{l}2 \\
2 \\
0\end{array}$ & $\begin{array}{l}\text { 苟 } \\
0 \\
0\end{array}$ & $\begin{array}{l}\text { 茪 } \\
0 \\
0 \\
0 \\
0\end{array}$ & 1 & 1 & \\
\hline$\therefore:$ & $\therefore$ & $\frac{3}{0}$ & ó & :ु & $\begin{array}{l}\infty \\
0 \\
0\end{array}$ & I & I & 1 & 1 & $\underset{\leftrightarrow}{\stackrel{\circ}{*}}$ & $\underset{-}{\infty}$ & $\stackrel{20}{-10}$ & & $\begin{array}{lll}2 \\
0 \\
0\end{array}$ & $\begin{array}{l}E \\
\text { O }\end{array}$ & $\begin{array}{l}\text { 范 } \\
\text { : }\end{array}$ & 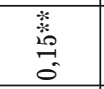 & 蒌 & 莣 & \\
\hline$\stackrel{\Delta}{s}$ & 의 & $\begin{array}{l}0 \\
? \\
0\end{array}$ & $\begin{array}{l}\overrightarrow{\text { जे }} \\
\text { o. }\end{array}$ & ฐิ & $\stackrel{8}{8}$ & đ̇ & $\stackrel{\infty}{0}$ & $\begin{array}{l}8 \\
: \\
0\end{array}$ & $\begin{array}{c}\infty \\
0 \\
0 \\
0 \\
0\end{array}$ & $\begin{array}{l}18 \\
0 \\
i\end{array}$ & $\begin{array}{l}\hat{D} \\
\text { ij }\end{array}$ & 득 & & $\mid \begin{array}{ll}10 \\
20 \\
0\end{array}$ & $\begin{array}{l}\text { E } \\
0\end{array}$ & $\begin{array}{l}* \\
0 \\
0 \\
0\end{array}$ & 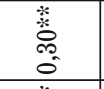 & 愚 & 站 & \\
\hline$\sigma=$ & $\Rightarrow$ & ఫี & $\begin{array}{l}\text { Sa } \\
\text { : }\end{array}$ & :ु & : & $\begin{array}{l}\text { : } \\
\stackrel{0}{0}\end{array}$ & ơ & 8 & त & 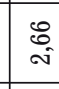 & $\stackrel{9}{\overbrace{}}$ & 呫 & & $\because 0$ & $\stackrel{\infty}{\infty}$ & 商 & 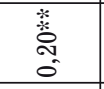 & $\stackrel{*}{*}$ & $\stackrel{*}{=}$ & 1 \\
\hline$\infty$ & in & $\vec{z}$ & 1 & $\begin{array}{l}\text { Jै } \\
\text { ठ }\end{array}$ & $\overrightarrow{0}$ & $\begin{array}{l}\text { sิy } \\
\text { ô }\end{array}$ & $\begin{array}{l}\vec{A} \\
\text { o. }\end{array}$ & $\stackrel{8}{0}$ & iv & $\begin{array}{l}\hat{b} \\
i\end{array}$ & $\mid \begin{array}{l}\hat{D} \\
\text { ij }\end{array}$ & $\stackrel{\infty}{\rightarrow}$ & & s. & $\begin{array}{l}0 \\
\stackrel{2}{0}\end{array}$ & $\begin{array}{l}* \\
* \\
0 \\
0 \\
0\end{array}$ & 恶 & $\stackrel{*}{*}$ & $=$ & $\begin{array}{l}* \\
\text { *a } \\
\text { oे } \\
\text { o }\end{array}$ \\
\hline$\therefore$ & 8 & 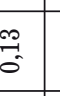 & \begin{tabular}{l}
$\infty$ \\
\hdashline \\
0 \\
0
\end{tabular} & $\stackrel{9}{2}$ & $\stackrel{8}{0}$ & 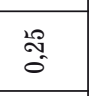 & $\stackrel{9}{2}$ & $\begin{array}{l}8 \\
0 \\
0\end{array}$ & $\lambda$ & 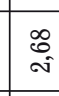 & 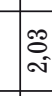 & $\stackrel{2}{\stackrel{2}{-}}$ & & 18 & 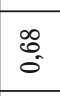 & 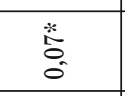 & 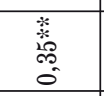 & $\stackrel{*}{*}$ & $\stackrel{*}{*}$ & \\
\hline 0 & 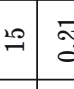 & ন̇ & : & 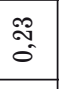 & 驾 & : & જ̊ & $\overrightarrow{0}$ & $\stackrel{\substack{9 \\
\hdashline}}{0}$ & $\underset{\stackrel{\circ}{\circ}}{\stackrel{8}{0}}$ & $\stackrel{\substack{\infty \\
\overbrace{}}}{-}$ & 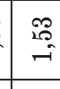 & & $\begin{array}{l}0 \\
0\end{array}$ & $\begin{array}{l}\infty \\
2 \\
0 \\
0\end{array}$ & 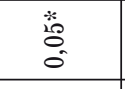 & $\begin{array}{l}\text { 茪 } \\
\text { ầ } \\
0\end{array}$ & 露 & 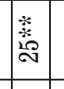 & \\
\hline$\therefore$ & $\vec{\omega}$ & $\begin{array}{l} \pm \\
0 \\
0\end{array}$ & 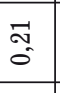 & $\stackrel{7}{0}$ & 苍 & $\begin{array}{l}\text { มू } \\
\text { ơ }\end{array}$ & $\stackrel{9}{3}$ & $\stackrel{8}{\circ}$ & בְ & 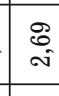 & 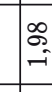 & $\stackrel{ }{=}$ & & $\left\{\begin{array}{l}13 \\
0 \\
0 \\
0\end{array}\right.$ & 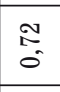 & 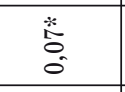 & 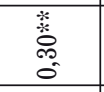 & 蛋 & 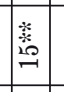 & \\
\hline$\nabla=$ & ন & ô & $\begin{array}{l}\text { ส̃ } \\
\text { o }\end{array}$ & : & $\begin{array}{l}8 \\
0 \\
0\end{array}$ & $\begin{array}{l}\text { : } \\
\stackrel{0}{0}\end{array}$ & ó & $\begin{array}{l}8 \\
0\end{array}$ & శ్ & $\begin{array}{l}\text { to } \\
\text { is }\end{array}$ & & ت & | & $\begin{array}{ll}2 \\
0 \\
0\end{array}$ & 롱 & $\begin{array}{l}\text { 䓂 } \\
\text { 定 }\end{array}$ & 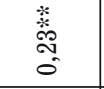 & $\stackrel{*}{*}$ & 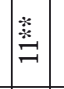 & $\begin{array}{l}\overline{0} \\
\text { ì } \\
\text { - }\end{array}$ \\
\hline$\infty \approx$ & \begin{tabular}{l|l}
$\curvearrowright$ \\
\hdashline
\end{tabular} & : & 今్ & $\stackrel{\infty}{0}$ & 范 & 品 & 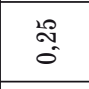 & $\stackrel{\infty}{\infty}$ & $\vec{\lambda}$ & $\stackrel{0}{i}$ & $\underset{-}{\infty}$ & $\vec{i}$ & & $\left\{\begin{array}{l}2 \\
0\end{array}\right.$ & 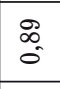 & 总 & 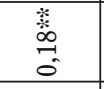 & I & 1 & 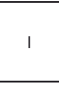 \\
\hline$\sim$ & ז & 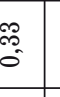 & 营 & : & $\Rightarrow$ & $\begin{array}{l}0 \\
: \\
:\end{array}$ & $\begin{array}{l}\text { స̃ } \\
\text { ơ }\end{array}$ & : & 尺. & 兽 & $\stackrel{\mathscr{I}}{\mathscr{I}}$ & $\underset{\sim}{\stackrel{N}{-}}$ & & i & $\begin{array}{l}0 \\
0 \\
0\end{array}$ & $\begin{array}{l}* \\
\stackrel{0}{\circ} \\
0\end{array}$ & $\begin{array}{l}\frac{1}{30} \\
0 \\
0\end{array}$ & 1 & 1 & 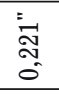 \\
\hline$-1=$ & $\circ \stackrel{\infty}{\circ}$ & $\stackrel{\infty}{\infty}$ & 1 & i⿱ & $\begin{array}{l}\infty \\
0 \\
0 \\
0\end{array}$ & 1 & 1 & 1 & & $\begin{array}{l}\stackrel{\circ}{\circ} \\
-i\end{array}$ & ঙ্ন & $\begin{array}{l}\infty \\
0 \\
0\end{array}$ & & $\begin{array}{l}0 \\
1 \\
-1\end{array}$ & ָૅ & $\begin{array}{l}\text { 商 } \\
0\end{array}$ & & 1 & 1 & \\
\hline 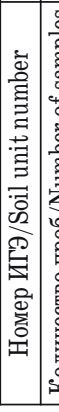 & 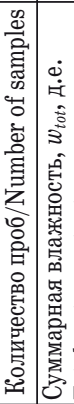 & 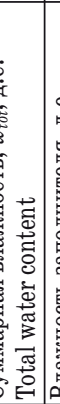 & 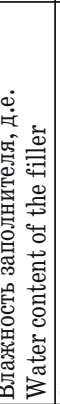 & 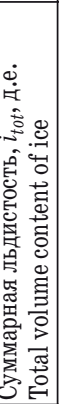 & 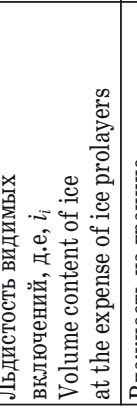 & 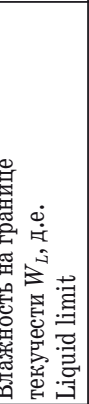 & 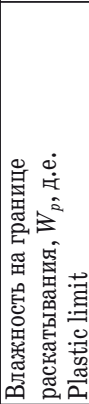 & 递 & 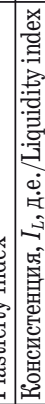 & 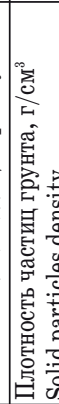 & 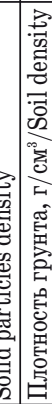 & 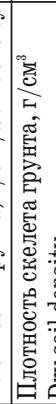 & 空 & $\begin{array}{l}0 \\
0 \\
0 \\
0\end{array}$ & 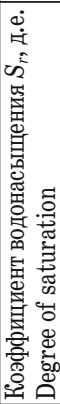 & 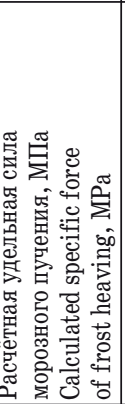 & 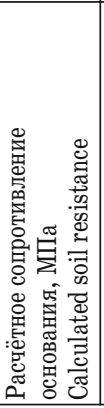 & 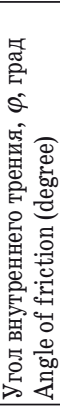 & 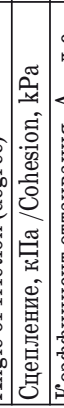 & 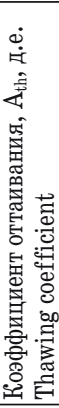 \\
\hline
\end{tabular}




\begin{tabular}{|c|c|c|c|c|c|c|c|c|c|}
\hline s & I & 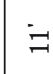 & & $\overrightarrow{0}$ & 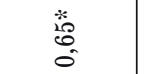 & 葛 & 莌 & 营 & \multirow{6}{*}{ 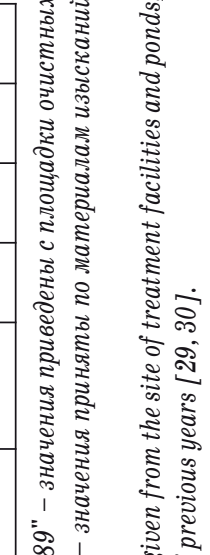 } \\
\hline & I & $\overline{7}$ & & $\begin{array}{l}\tilde{O} \\
0 \\
0\end{array}$ & 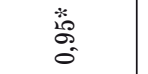 & $\stackrel{*}{\stackrel{*}{二}}$ & 蒙 & 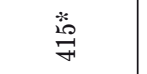 & \\
\hline 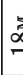 & I & 蕫 & & $\tilde{\delta}$ & 苋 & $\stackrel{*}{\stackrel{\circ}{\circ}}$ & 总 & 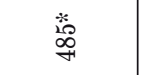 & \\
\hline$\alpha$ & I & 蒡 & & $\begin{array}{l}0 \\
0 \\
0\end{array}$ & 惫 & 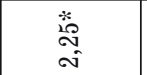 & 蒿 & 䓲 & \\
\hline 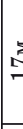 & 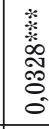 & 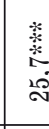 & & $\stackrel{8}{8}$ & 总 & 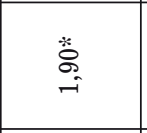 & 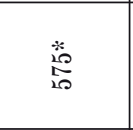 & 蓄 & \\
\hline 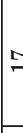 & 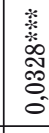 & 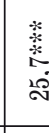 & & : & 总 & 蒿 & $\begin{array}{l}\text { 总 } \\
\text { 总 }\end{array}$ & 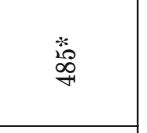 & \\
\hline 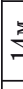 & 1 & 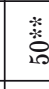 & & $\begin{array}{l}0 \\
0 \\
0\end{array}$ & 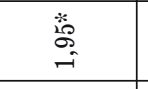 & 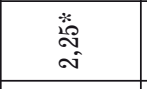 & 。ั & $\begin{array}{l}\stackrel{*}{*} \\
\stackrel{H}{10}\end{array}$ & \\
\hline 5 & I & 蒡 & & $\overrightarrow{0}$ & 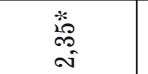 & 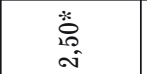 & 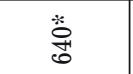 & 薯 & \\
\hline ช & I & 晜 & & $\overrightarrow{0}$ & 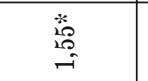 & $\begin{array}{l}\text { 商 } \\
\text { 尊 }\end{array}$ & 荅 & 蓠 & \\
\hline ศ & 1 & 薂 & & $\begin{array}{l}\overrightarrow{0} \\
0\end{array}$ & 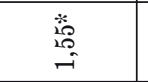 & 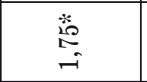 & 莨 & 蒂 & \\
\hline ᄀ & I & I & & $\begin{array}{l}\mathscr{0} \\
: \\
0\end{array}$ & $\begin{array}{l}\text { 总 } \\
\text { 尊 }\end{array}$ & 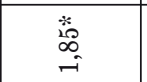 & 浐 & 䕃 & \\
\hline 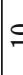 & 1 & $\stackrel{*}{*}$ & & $\begin{array}{l}\overline{\text { o }} \\
\text { O. }\end{array}$ & 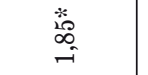 & 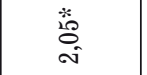 & $\stackrel{*}{\stackrel{*}{0}}$ & 䓂 & \\
\hline 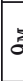 & 1 & $\underset{\mathrm{N}}{*}$ & & $\begin{array}{l}\text { II } \\
\text { : }\end{array}$ & 悉 & 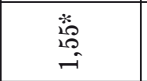 & 蒿 & 蒫 & \\
\hline 。 & I & $\underset{0}{*}$ & & $\begin{array}{l}\text { क्ष } \\
\text { d. } \\
0\end{array}$ & $\underset{\sim}{\stackrel{*}{*}}$ & 蔏 & $\stackrel{*}{\stackrel{0}{0}}$ & $\stackrel{*}{\stackrel{*}{\circ}}$ & \\
\hline & 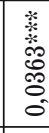 & 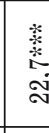 & & $\begin{array}{l}0 \\
0 \\
0 \\
0\end{array}$ & 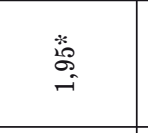 & $\begin{array}{l}\text { 莡 } \\
\text { âd }\end{array}$ & 产 & 兽 & 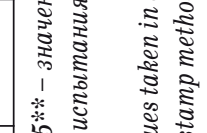 \\
\hline & I & 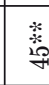 & & $\begin{array}{l}\tilde{0} \\
\dot{0} \\
0\end{array}$ & 荾 & 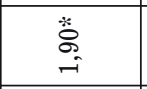 & $\begin{array}{l}\text { 类 } \\
\text { 点 }\end{array}$ & 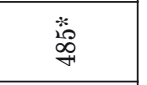 & \\
\hline 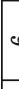 & 1 & 䓠 & & $\begin{array}{l}\text { 落 } \\
0 \\
0\end{array}$ & 总 & 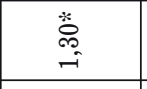 & $\stackrel{*}{\stackrel{0}{0}}$ & 总 & \\
\hline & 1 & $\underset{\sim}{*}$ & & $\begin{array}{l}\text { Oे } \\
0\end{array}$ & 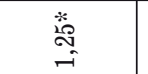 & 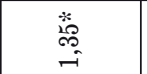 & 蒿 & 萨 & \\
\hline & \begin{tabular}{|l}
0 \\
0 \\
0 \\
0 \\
0
\end{tabular} & $\begin{array}{l}\infty \\
\infty \\
\infty \\
\infty\end{array}$ & & $\begin{array}{l}\vec{E} \\
0 \\
0\end{array}$ & $\underset{\sim}{\stackrel{*}{*}}$ & 䒿 & : & 䓂 & \\
\hline & 1 & I & & $\begin{array}{l}\infty \\
0 \\
0 \\
0\end{array}$ & 1 & 1 & 蒿 & 蒿 & \\
\hline & 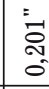 & 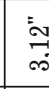 & & $\begin{array}{l}8 \\
\vdots \\
0\end{array}$ & 1 & 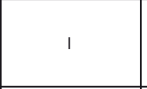 & 产 & 落 & \\
\hline . & I & । & & $\begin{array}{l}\text { Oै } \\
\text { O. } \\
0\end{array}$ & 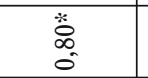 & 商 & 。ㅎㅇ & 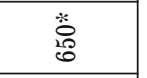 & \\
\hline 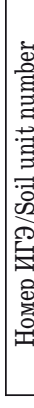 & 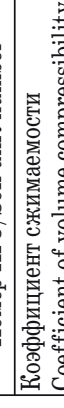 & 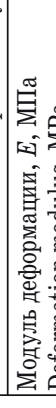 & & 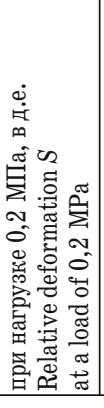 & 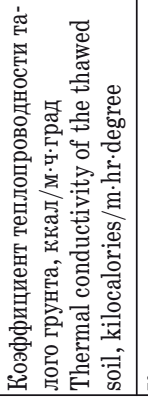 & 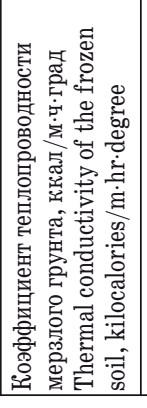 & 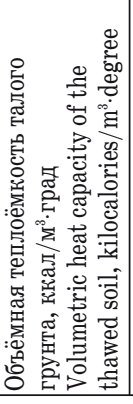 & 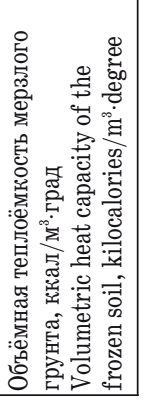 & 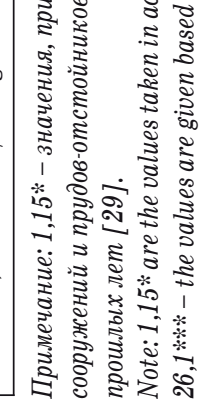 \\
\hline
\end{tabular}


кальное распространение по площади, вскрыт под почвенно-растительным слоем, мощностью $0,5 \ldots 3,5 \mathrm{~m}$.

ИГЭ-З Заторфованный грунт темно-серый, коричневый, желто-коричневый, имеет локальное распространение по площади, вскрыт с поверхности под почвенно-растительным слоем и с глубины $2,1 \mathrm{м}$, мощностью $0,2 \ldots 2,4 \mathrm{~m}$.

ИГЭ-4 Супесь с әресвой от 1 до $25 \%$, темно-серая, серая, темно-коричневая. Грунт имеет локальное распространение по площади, вскрыт с поверхности под почвенно-растительным слоем и с глубины $0,5 \ldots 1,1 \mathrm{~m}$, мощностью $0,3 \ldots 4,0 \mathrm{~m}$.

ИГЭ-5 Супесь дресвяная коричневато-серая, серо-зеленая, желто-коричневая. Грунт имеет ограниченное распространение по площади, вскрыт с поверхности под почвенно-растительным слоем и с глубины $0,4 \ldots 2,0 \mathrm{M}$, мощностью $0,6 \ldots 3,5 \mathrm{M}$.

ИГЭ-6 Суглинок с әресвой от 4 до $24 \%$, коричневый, светло-коричневый, зеленовато-серый, имеет локальное распространение по площади, вскрыт с поверхности под почвенно-растительным слоем и с глубины $0,5 \ldots 1,3 \mathrm{~m}$, мощностью $1,2 . .2,5$ м.

ИГЭ-7 Дресвяный грунт с супесчаныл заполнителел до $30 . . .48$ \% , имеет повсеместное распространение по площади, вскрыт как с поверхности под почвенно-растительным слоем, так и с глубины $0,5 . .2,4$ м, мощностью $0,8-2,8$ м.

ИГЭ-8 Щебенистый грунт с супесчаным, суглинистым и песчаным заполнителем до 11-39 \%, имеет повсеместное распространение по площади, вскрыт как с поверхности под почвенно-растительным слоем, так и с глубины $0,6 . . .2,5$ м, мощностью $0,5 \ldots 3,4 \mathrm{~m}$.

ИГЭ-9 Супесь гравелистая от серовато-коричневого до темно-серого цвета. Грунт имеет ограниченное распространение по площади, вскрыт под почвенно-растительным слоем и с глубины $0,5 \ldots 1,6$ м, мощностью $0,9 \ldots 3,5$ м.

ИГЭ-9м Супесь гравелистая твердомерзлая коричневого цвета, имеет локальное распространение по площади, вскрыта с глубины 2,5...3,5 м, мощностью $1,7 \ldots 5,7$ м.

ИГЭ-10 Песок пылеватый от желто-коричневого до темно-серого цвета, с включением гравия до 3-20\%. Грунт имеет ограниченное распространение по площади. Вскрыт под почвенно-растительным слоем и с глубины $0,8 . . .3,2$ м, мощностью $0,8 \ldots 2,5 \mathrm{~m}$.

ИГЭ-12 Песок гравелистый серо-коричневый, коричневый, имеет ограниченное распространение по площади, вскрыт под почвенно-растительным слоем и с глубины 1,8 м, мощностью $0,8 . . .1,8$ м.

ИГЭ-13 Галечниковый грунт с супесчаныл заполнителел до 30-49 \% коричневого и коричневато-серого цвета. Грунт имеет локальное распространение по площадке, вскрыт с поверхности под почвенно-растительным слоем и с глубины $0,8 \ldots 1,9$ м, мощностью $0,5 \ldots 4,0$ м.

ИГЭ-13л Галечниковый грунт с супесчаныл заполнителел твердомерзлый. Заполнитель ко- ричневато-серого и коричневого цвета до $31 . .49 \%$. Грунт имеет локальное распространение по площади, вскрыт с глубины 2,0...4,0 м, вскрытой мощностью $1,5 . . .6,0$ м.

ИГЭ-14 Галечниковый грунт с супесчаным и песчаным заполнителем до $18 . . .28$ \% серо-коричневого и коричневого цвета. Грунт имеет локальное распространение по площадке, вскрыт с поверхности под почвенно-растительным слоем и с глубины $0,8 . .2,0$ м, мощностью $1,3 . . .3,8$ м.

ИГЭ-14м Галечниковый грунт твердомерзлый с супесчаным и песчаным заполнителем до $13 . . .28 \%$ серо-коричневого и коричневого цвета. Грунт имеет локальное распространение по площадке, вскрыт с глубины 2,0...5,2 м, вскрытой мощностью $0,7 . . .9,1 \mathrm{м}$.

ИГЭ-17 Песчаник "рухляк» коричневато-серого, серого, желтовато-коричневого и коричневого цвета, сильновыветрелый до щебня, дресвы, супеси и песка. Грунт вскрыт локально, в основном в кровле скального массива с глубины 1,0...15,6 м, вскрытой мощностью $0,5 \ldots 3,0 \mathrm{M}$

ИГЭ-17л Песчаник "рухляк» твердолерзлый коричневато-серого, серого, желтовато-коричневого и коричневого цвета, сильновыветрелый до щебня, дресвы, супеси и песка. Грунт вскрыт локально с глубины 2,2...15,6 м, вскрытой мощностью $0,7 \ldots 5,6 \mathrm{~m}$.

таблица 2. Нормативные значения физико-механических свойств скальных грунтов

Table 2. Average values of physical and mechanical properties of rocks

\begin{tabular}{|c|c|c|c|c|c|c|c|}
\hline \multirow{2}{*}{ 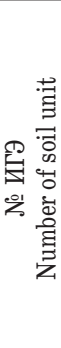 } & \multirow{2}{*}{$\begin{array}{c}\text { Наименование } \\
\text { ИГЭ } \\
\text { Name of soil unit }\end{array}$} & \multirow{2}{*}{ 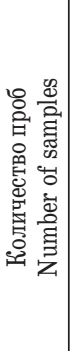 } & \multirow{2}{*}{ 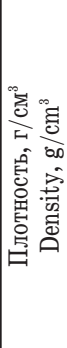 } & \multirow{2}{*}{ 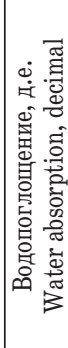 } & \multicolumn{2}{|c|}{$\begin{array}{l}\text { Временное сопро- } \\
\text { тивление сжа- } \\
\text { тию, МПа } \\
\text { Strength in uni- } \\
\text { axial compres- } \\
\text { sion, MPa }\end{array}$} & \multirow{2}{*}{ 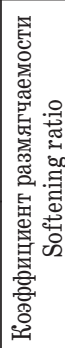 } \\
\hline & & & & & 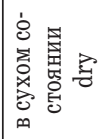 & 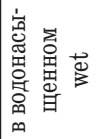 & \\
\hline $20 \mathrm{M}$ & $\begin{array}{l}\text { Песчаник } \\
\text { малопрочный } \\
\text { Low strength } \\
\text { sandstone }\end{array}$ & 34 & 2,52 & 0,020 & 30,0 & 12,2 & 0,44 \\
\hline $21 \mathrm{M}$ & $\begin{array}{l}\text { Песчаник сред- } \\
\text { ней прочности } \\
\text { Medium strength } \\
\text { sandstone }\end{array}$ & 488 & 2,55 & 0,015 & 57,8 & 33,1 & 0,57 \\
\hline $22 \mathrm{M}$ & $\begin{array}{l}\text { Песчаник } \\
\text { прочный } \\
\text { High strength } \\
\text { sandstone }\end{array}$ & 240 & 2,61 & 0,011 & 102,5 & 68,4 & 0,67 \\
\hline $23 \mathrm{M}$ & $\begin{array}{l}\text { Алеврит средней } \\
\text { прочности } \\
\text { Medium strength } \\
\text { siltstone }\end{array}$ & 14 & 2,59 & 0,015 & 65,8 & 38,6 & 0,59 \\
\hline $24 \mathrm{M}$ & $\begin{array}{l}\text { Алеврит } \\
\text { малопрочный } \\
\text { Low strength } \\
\text { siltstone }\end{array}$ & 18 & 2,55 & 0,018 & 20,5 & 9,8 & 0,48 \\
\hline
\end{tabular}


ИГЭ-18 Алевролит «рухляк» темно-серого, коричневого, зеленовато-коричневого цвета. Грунт сильновыветрелый до щебня, дресвы, супеси и суглинка, вскрыт локально с глубины $0,8 \ldots 3,5 \mathrm{~m}$, мощностью $0,3 \ldots 5,5$ м (рис. 2).

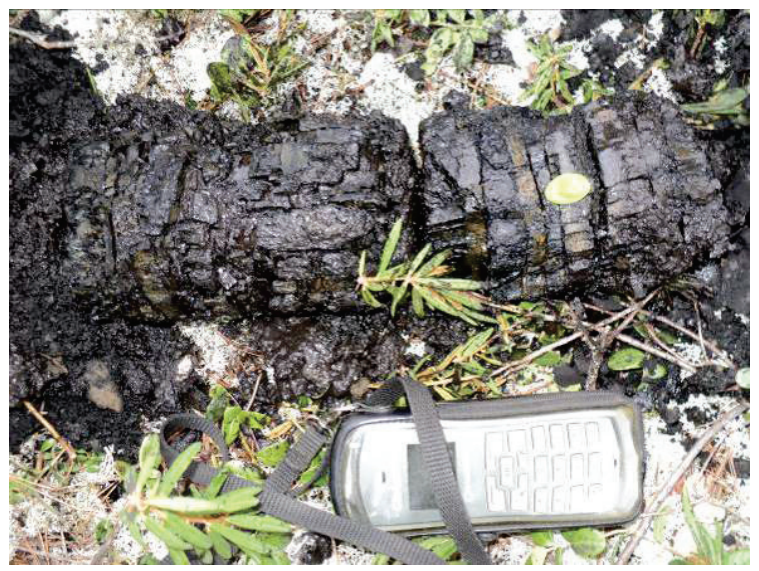

Pис. 2. Керн угля с линзами алевролита рухляка [30]

Fig. 2. Core sample of coal with lenses of siltstone marl [30]

ИГЭ-18л Алевролит «рухляк» твердолерзльй темно-серого, коричневого, зеленовато-коричневого цвета. Грунт сильновыветрелый до щебня, дресвы, супеси и суглинка. Вскрыт локально с глубины $3,2 \ldots 15,0$ м, вскрытой мощностью $0,2 \ldots 4,6$ м.

ИГЭ-19 Уголь черный, блестящий, выветрелый, с прослойками черного углистого алевролита вскрыт локально по площади в толще песчаников и алевролитов с глубины $0,3 \ldots 3,8$ м, вертикальной мощностью 0,3...1,8 м. Залегание пород моноклинальное с пологими (5) углами падения на юго-запад.

ИГЭ-19л Уголь твердолерзлый черный, блестящий, выветрелый, с прослойками черного углистого алевролита, вскрыт локально по площади в толще песчаников и алевролитов с глубины $3,8 . . .33,7$ м, вертикальной мощностью $0,2 . .1,4$ м.

ИГЭ-20м Песчаник малопрочный серого, серокоричневого, желто-коричневого и темно-серого цвета, тонко-мелкозернистый, очень сильнотрещиноватый, трещины ориентированы хаотично и под углами $0 . .15,40 \ldots 55$ и $80 . .85^{\circ}$ к оси керна. Грунт вскрыт практически повсеместно по площади с глубины 1,3...37,7 м, вскрытой мощностью $0,4 \ldots 22,3 \mathrm{M}$.

ИГЭ-21.м Песчаник средней прочности серого, серо-зеленого, серо-коричневого цвета, тонко-мелкозернистый, с маломощными прослойками алевролита и угля. Грунт очень сильнотрещиноватый до трещиноватого, трещины ориентированы хаотично и под углами $0 . .15,40 \ldots 55$ и $80 \ldots 85^{\circ}$ к оси керна. Грунт вскрыт повсеместно по площади с глубины $0,3 \ldots 34,0$ м, вскрытой мощностью $0,4 \ldots 38,0 \mathrm{~m}$.

ИГЭ-22л Песчаник прочный серого, серо-зеленого, серо-коричневого цвета, тонко-мелкозерни- стый, с маломощными прослойками алевролита и угля. Грунт очень сильнотрещиноватый до трещиноватого, трещины ориентированы хаотично и под углами $0 . . .15,40 . .55$ и $80 . .85^{\circ}$ к оси керна. Грунт вскрыт повсеместно по площади с глубины $1,7 \ldots 56,0$ м, вскрытой мощностью $1,3 \ldots 26,2$ м.

ИГЭ-23л Алевролит средней прочности серый и темно-серый, тонкозернистый, с маломощными углистыми прослойками, сильнотрещиноватый и очень сильнотрещиноватый, трещины ориентированы хаотично и под углами $0 . .15,40 \ldots 55$ и $80 . .85^{\circ}$ к оси керна. Грунт вскрыт локально по площади с глубины $2,0 \ldots 27,5$ м, вскрытой мощностью $0,7 \ldots 5,5 \mathrm{~m}$.

ИГЭ-24л Алевролит малопрочный серый, зеленовато-серый, темно-серый, тонкозернистый, сильнотрещиноватый и очень сильнотрещиноватый, с маломощными углистыми прослойками, трещины ориентированы хаотично и под углами $0 \ldots 15,40 \ldots 55$ и $80 \ldots 85^{\circ}$ к оси керна. Грунт вскрыт локально по площади с глубины $2,2 \ldots 34,0$ м вскрытой мощностью 0,5...12,6 м.

\section{Инженерно-геологическое районирование} площадки по несущей способности грунтов

Исследование проведено осенью 2018 г. в отделении геологии ТПУ и включало анализ информации, полученной из фондов изыскательской компании, установление принципов и методики районирования. В основу районирования были положены следующие факторы: геоморфологические условия; геологическое строение (литологический состав и несущая способность грунта, первого под почвенно-растительным слоем, его мощность); гидрогеологические и мерзлотные условия; наличие геологических процессов и явлений. Все информационные слои о природной среде обрабатывались с помощью геоинформационной системы (ГИС), а затем объединялись для получения единой инженерно-геологической карты в AutoCAD.

По пригодности участков к строительному освоению были выделены три категории районов с благоприятными, приемлемыми и неблагоприятными условиями (рис. 3, табл. 3). Выделенные районы отличаются геоморфологическими условиями, литологическим составом пород и соответствующей составу несущей способностью. Грунты площадки находятся повсеместно в мерзлом состоянии, поэтому этот фактор не использовался при выделении районов. Однако следует учесть, что в процессе строительства и эксплуатации промплощадки при оттаивании мерзлых грунтов могут происходить неравномерные осадки грунта из-за неравномерного оттаивания, а также из-за различной льдистости грунта, что потребует проведение мероприятий по уменьшению этих осадок.

I категория по условиям строительства характеризуется как благоприятная. К данной категории относятся участки, сложенные ИГЭ № 7, 8, 12,13, имеющие высокую несущую способность. 
таблица 3. Экспликация к карте районирования

Table 3. Legend to the zoning map

\begin{tabular}{|c|c|c|c|c|c|}
\hline $\begin{array}{l}\text { Категория района } \\
\text { по условиям строительства } \\
\text { Category of district under } \\
\text { the terms of the construction }\end{array}$ & $\begin{array}{c}\text { Обозначение } \\
\text { Marking }\end{array}$ & $\begin{array}{c}\text { Геоморфологические } \\
\text { условия } \\
\text { Geomorphological } \\
\text { conditions }\end{array}$ & $\begin{array}{c}\text { Номер 1-го от } \\
\text { поверхности ИГЭ } \\
\text { Number of the } 1^{\text {st }} \\
\text { soil unit }\end{array}$ & $\begin{array}{l}\text { Несущая спо- } \\
\text { собность, МПа } \\
\text { Bearing сарасі- } \\
\text { ty, MPa }\end{array}$ & $\begin{array}{c}\text { Геологические процессы } \\
\text { Geological processes }\end{array}$ \\
\hline $\begin{array}{c}\text { I - благоприятные } \\
\text { favourable }\end{array}$ & & $\begin{array}{c}\text { Плоские водоразделы, } \\
\text { пологие склоны } \\
\text { lat watersheds, } \\
\text { gentle slopes }\end{array}$ & $7,8,12,13$ & $0,3-0,6$ & $\begin{array}{c}\text { Слабая заболоченность, редко морозное } \\
\text { выпучивание крупнообломочного мате- } \\
\text { риала, линейная эрозия } \\
\text { Weak bogginess, rare frosty buckling of } \\
\text { coarse-grained material, linear erosion }\end{array}$ \\
\hline $\begin{array}{l}\text { II - приемлемые } \\
\text { acceptable }\end{array}$ & & $\begin{array}{c}\text { Склоны средней } \\
\text { крутизны (7-15) } \\
\text { Average slopes }\end{array}$ & $4,5,6,9,10$ & $0,2-0,3$ & $\begin{array}{l}\text { Морозное выпучивание крупнообломоч- } \\
\text { ного материала } \\
\text { Frosty buckling of coarse-grained material }\end{array}$ \\
\hline $\begin{array}{c}\text { III - неблагопрятные } \\
\text { unfavourable }\end{array}$ & & \begin{tabular}{|c|} 
Долины средних \\
и малых рек. \\
Крутые склоны $\left(>15^{\circ}\right)$ \\
Valleys of medium and \\
small rivers. Steep slopes
\end{tabular} & $1,2,3,4$ & $0,1-0,2$ & $\begin{array}{c}\text { Морозное выпучивание крупнообломоч- } \\
\text { ного материала, заболоченность долин } \\
\text { Frosty buckling of coarse-grained materi- } \\
\text { al, swampy valleys }\end{array}$ \\
\hline
\end{tabular}

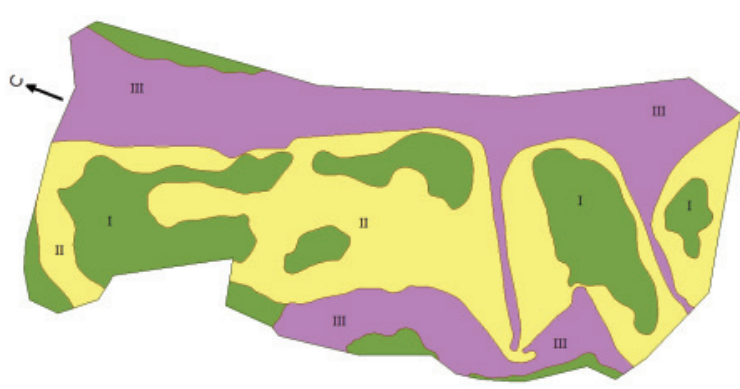

Pис. 3. Карта инженерно-геологического районирования площадки по несущей способности (Масштаб 1:5000)

Fig. 3. Map of engineering-geological zoning on bearing capacity of soils (at scale 1:5000)

II категория с приемлемыми условиями для строительства. Эта категория занимает значительное пространство в пределах площади. Участки этой категории сложены ИГЭ № 4, 5, 6, 9, 10 со средней несущей способностью. Эксплуатация таких участков требует специальных инженерных мер защиты.

III категория с неблагоприятными условиями для строительства - это долины средних и малых рек, часто заболоченные или крутые склоны (с уклонами более $\left.15^{\circ}\right)$. С поверхности залегают ИГӘ № 1, 2, 3, 4 с невысокой несущей способностью. Использование таких участков возможно только после проведения мероприятий инженерной мелиорации.

\section{Выводы}

Приведена инженерно-геологическая оценка территории промплощадки для установления ее

\section{СПИСОК ЛИТЕРАТУРЫ}

1. Афанасиади Э.И., Абатурова И.В., Тарасевич А.В. Опыт инженерно-геологического районирования территории строительства Воронцовского ГОКа с целью рационального использования и охраны геологической среды / Известия Уральского государственного горного университета. - 2001. - Т. 13. C. 241-246.

2. The influence of components of engineering-geological conditions on mineral mining in permafrost zone / I.V. Abaturova, L.A. Sto- пригодности к застройке. Для этого рассмотрены основные природные компоненты: литология; топография; сейсмотектоника; геотехника; гидрология, гидрогеология и вечная мерзлота. В целом инженерно-геологические условия площадки являются достаточно сложными в связи с высокой сейсмической активностью района, наличием многолетней мерзлоты и таких геологических процессов, как поверхностное заболачивание площадки, морозное выпучивание каменного материала на склонах водоразделов, морозное пучение несвязных грунтов в зимний период и присутствие в разрезе сильно трещиноватых углей, алевролитов и песчаников «рухляков».

Все информационные слои о природной среде обрабатывались, затем объединялись для получения единой инженерно-геологической карты. На разработанной карте инженерно-геологического районирования выделены три категории районов с благоприятными, приемлемыми и неблагоприятными условиями для строительства, по геоморфологическим условиям, литологическому составу пород и их несущей способности. Дана характеристика выделенных категорий районов. $\mathrm{Pa}$ йонирование территории по этим признакам может служить основой для принятия обоснованных решений при проектировании инженерных сооружений, базой для организации мониторинга, экспертизы.

Исследование выполнено в Томском политехническом университете в рамках програмлы повышения конкурентоспособности Толского политехнического университета (средства ВИУ).

rozhenko, I.G. Petrova, I.A. Koroleva // Gornyi Zhurnal. 2015.- V. 9. - P. 22-27.

3. Грязнов 0.Н. Инженерно-геологические условия Урала: науч. моногр. - Екатеринбург: Изд-во Уральского государственного горного университета, 2017. - 240 c.

4. Ольховатенко В.Е. и др. Инженерная геология угольных месторождений Сибири и Дальнего Востока. Закономерности формирования инженерно-геологических условий угольных месторождений // под общ. ред. д.г.-м.н., проф. В.Е. Ольхова- 
тенко. - Томск: Изд-во Томского государственного университета, 1992. -Т. 1. -288 c.

5. Ольховатенко В.Е. и др. Инженерная геология угольных месторождений Сибири и Дальнего Востока. Инженерно-геологическая типизация угольных месторождений и оценка устойчивости бортов карьеров // под общ. ред. д.г.-м.н., проф. В.Е. Ольховатенко. - Томск: Изд-во Томского государственного университета, 1992. - Т. 2. - 258 с.

6. Нифантов Ф.П., Пуляев В.Н. Вопросы методики инженерно-геологических исследований буроугольных исследований Сибири на стадии предварительной разведки // Инженерно-геологические условия строительства крупных карьеров в Сибири. - Томск: Изд-во Томского государственного университета, 1973. - 260 с.

7. Ольховатенко В.Е., Трофимова Г.И. Инженерно-геологические условия разработки открытым способом угольных месторождений Ерунаковского района Кузбасса и оценка состояния окружающей среды. - Томск: Изд-во Томского государственного архитектурно-строительного университета, 2011. - 204 с.

8. Щербак Г.Г. Закономерности формирования инженерно-геологических условий угольных месторождений Восточной Сибири и их влияние на устойчивость бортов карьеров: автореф. дис. ... д-ра геол.-минерал. наук. - Томск, 2003. - 55 с.

9. Ganova S.D. Geoecological aspects of creation and functioning of natural and technical systems in the conditions of the cryolithozone of Western Siberia // Proceedings of Higher Schools. Geology and exploration. - 2017. - № 5. - P. 58-64.

10. Influence of coal mining on groundwater resources and countermeasures in Shanbei energy and chemical base / M.S. Zhang, Y. Dong, R.J. Du, X.F. Gu // Earth Science Frontiers. - 2010. V. 17 (6). - P. 235-246.

11. Effects of coal mining on shallow water resources in semiarid regions: a case study in the Shennan mining area, Shaanxi, China / W. Qiao, W.P. Li, T. Li, J.Y. Chang, Q. Wang // Mine Water Environment. - 2017. - V. 36 (1). - P. 104-113.

12. Wang K., Lin Z.B., Zhang R.D. Impact of phosphate mining and separation of mined materials on the hydrology and water environment of the Huangbai River basin, China // Sci. Total Environment. - 2016. - V. 543. - P. 347-356.

13. Research and development of the mine geological environment evaluation system / W.W. Jia, G.D. Bao, X.W. Wu, S.W. Jiang, C. Zhai // Advanced Materials Research. - 2011. - V. 270. - P. 1354-1359.

14. Variations in the building site categories in the underground mining region of Doubrava (Czech Republic) for land use planning / M. Marschalko, I. Yilmaz, M. Bednárik, K. Kubecka // Engineering Geology. - 2011. - V. 122. - P. 169-178.

15. Ullah K.M., Mansourian A. Evaluation of land suitability for urban land-use planning: Case study Dhaka city // Transactions in GIS. - 2016. - V. 20 (1). - P. 20-37.

16. Martínez-Graña A.M., Goy J.L., Zazo C. Engineering geology maps for planning and manegement of natural parks: «Las Batuecas-Sierra de Francia» and "Quilamas», (Central Spanish System, Salamanca, Spain) // Geosciences. - 2013. - V. 1. - P. 46-62.

17. Гриб Н.Н., Кузнецов П.Ю. Прогнозирование физико-механических свойств углевмещающих пород на основе данных геофизических исследований скважин и математического аппарата Марковской нелинейной статистики // Уголь. - 2018. - № 1. - С. 68-73.

18. Скоморошко Ю.Н. Оценка устойчивости горных пород в бор- тах карьеров по результатам геофизических исследований скважин (на примере Эльгинского месторождения): дис. ... канд. техн. наук. - Нерюнгри, 2001. - 181 с.

19. Хоютанов Е.А. Обоснование резервов совершенствования процессов управления зольностью угля при разработке сложноструктурных месторожжений (на примере Эльгинского месторождения): дис. ... канд. техн. наук. - Якутск, 2016. - 155 с.

20. Бердюгин В.А. Условия отработки «Эльгинского» месторождения каменных углей и планируемые комплексы оборудования для его разработки // Горный информационно-аналитический бюллетень. Отдел. выпуск. - 2009. - № 10. - С. 373-379.

21. Николаева Н.А., Пинигин Д.Д. Оценка факторов техногенного воздействия на природную среду Эльгинского угольного комплекса // Современные проблемы науки и образования. 2014. - № 5. URL: www.science-education.ru/119-14545 (дата обращения: 05.11.2018).

22. Трофимов В.Т., Красилова Н.С. Инженерно-геологические карты. - М.: КДУ, Добросвет, 2018. - 383 с.

23. Строкова Л.А., Ермолаева А.В. Районирование территории по степени опасности оседания земной поверхности при проектировании магистрального газопровода в южной Якутии // Известия Томского политехнического университета. Инжиниринг георесурсов. - 2016. - Т. 327. - № 10. - С. 59-68.

24. Strokova L.A. Modeling of tunneling-induced ground surface movement // IOP Conf. Series: Earth and Environmental Science. 2015. - V. 24. $-6 \mathrm{p}$.

25. Strokova L.A., Teterin E.A. Identification, diagnosis and ranking of risks of geohazard in pipeline and urbanized territories // IOP Conference Series: Earth and Environmental Science. - 2016. - V. 43. - 6 p.

26. Purgina D.V., Strokova L.A., Kuzevanov K.I. Modeling of changing hydrogeological conditions during construction of pier foundations on the Kama river bank // IOP Conference Series: Earth and Environmental Science. - 2016. - V. 33. - 6 p.

27. Cheskidov V.V., Manevich A.I. Engineering and geological support for slope stability monitoring as a part of transport infrastructure construction projects // Mining science and technology. -2016 . - № 1. - C. 50-57.

28. Государственная геологическая карта Российской Федерации. Масштаб 1:1000000 (третье поколение). Серия Алдано-Забайкальская. Лист 0-52 - Томмот. Объяснительная записка / А.В. Радьков, А.В. Молчанов, А.В. Терехов, Е.В. Беленко и др. - СПб.: Картографическая фабрика Всероссийского научно-исследовательского геологического института им. А.П. Карпинского (ВСЕГЕИ), 2016. - 276 с.

29. Отчет об инженерно-геологических изысканиях на объекте: «Проект вскрытия участка первоочередной отработки Эльгинского месторождения в пределах Северо-западного участка» / А.В. Осьмушкин, Н.В. Осьмушкина и др. - Нерюнгри: Нерюнгристройизыскания, 2009. - $164 \mathrm{c.}$

30. Отчет о производстве инженерно-геологических изысканий на объекте: «Эльгинский горно-обогатительный комплекс. I очередь строительства» на стадии проектная документация / А.В. Осьмушкин, Н.В. Осьмушкина и др. - Нерюнгри: Нерюнгристройизыскания, 2010. - 1314 с.

Поступила 10.12.2018 2.

\section{Информация об авторах}

Строкова Л.А., доктор геолого-минералогических наук, профессор отделения геологии Инженерной школы природных ресурсов Национального исследовательского Томского политехнического университета.

Длитриева C.A., аспирант отделения геологии Инженерной школы природных ресурсов Национального исследовательского Томского политехнического университета.

Осьмушкина Н.B., генеральный директор 000 «Нерюнгристройизыскания» .

осьлушкин А.В., главный инженер 000 «Нерюнгристройизыскания». 
UDC 624.131

\section{EXPERIENCE OF ENGINEERING-GEOLOGICAL ZONING ON BEARING CAPACITY OF SOILS OF THE INDUSTRIAL SITE OF ELGA COAL-PREPARATION PLANT IN YAKUTIA}

Lyudmila A. Strokova', sla@tpu.ru

Sofia A. Dmitrieva',

dmitrieva_sa93@mail.ru

Natalia V. Osmushkina²,

yjtisiz@nery.sakha.ru

Andrey V. Osmushkin²,

yjtisiz@nery.sakha.ru

1 National Research Tomsk Polytechnic University,

30, Lenin Avenue, Tomsk, 634050, Russia.

${ }^{3}$ Neryungristroyizyskaniya,

1, YakutTisiz street, Neryungri, 678960, Russia.

The study is relevant due to the rapid growth of mining exploration and production activities in the permafrost regions of Russia over the last forty years. This paper presents the characteristics of the soils of the industrial site of Elga coal-preparation plant in the Republic of Sakha (Yakutia) on the bearing capacity. An engineering-geological evaluation is necessary to prepare decision making on land planning and land use of the area as well as to carry out the required industrial and infrastructure development with slight impact on breakable environment, which will be accompanied by reducing hazards and damage to constructions with consequent savings to people and property.

This study aims to describe the engineering-geological and hydrogeological conditions, exogenous geological processes that may be relevant to establish suitability for development.

Object of the research is the geological environment. The authors have considered the main natural components, which influence land use planning and development, such as lithology; topography; seismotectonic; geotechnic; hydrology-hydrogeology and permafrost. Methods. This study includes a brief review of relevant literature, and a summary of information obtained from geological survey company files. All information layers about the natural environment were manipulated and combined to produce uniform engineering geological map. Results. We produced a suitability map of the study area that shows three different zones such as favourable, acceptable and unfavourable conditions for building construction.

Key words:

Coal-preparation plant, open-pit mining, soil, coal, geological process, physical and mechanical properties, bearing capacity, zoning.

The research was carried out at Tomsk Polytechnic University within the Program of the University Competitiveness Enhancement (VIU funds).

\section{REFERENCES}

1. Afanasiadi E.I., Abaturova I.V., Tarasevich A.V. Opyt inzhenerno-geologicheskogo rayonirovaniya territorii stroitelstva Vorontsovskogo GOKa s tselyu ratsionalnogo ispolzovaniya i okhrany geologicheskoy sredy [Experience of engineering-geological zoning of the territory of construction of Vorontsov GOK for rational use of the geological environment protection]. News of the Ural state mining University, 2001, vol. 13, pp. 241-246.

2. Abaturova I.V., Storozhenko I.A., Korolyova I.G. Influence of the components of engineering-geological conditions on the extraction of minerals in the permafrost zone. Mining journal, 2015, vol. 9, pp. 22-27.

3. Gryaznov 0.N. Inzhenerno-geologicheskie usloviya Urala [Engineering-geological conditions of the Urals: scientific monograph]. Ekaterinburg, Ural state mining university, 2017. 240 p.

4. Olkhovatenko V.E. Inzhenernaya geologiya ugolnykh mestorozhdeniy Sibiri i Dalnego Vostoka. Zakonomernosti formirovaniya inzhenerno-geologicheskikh usloviy ugolnykh mestorozhdeniy [Engineering Geology of coal deposits of Siberia and the Far East. Regularities of formation of engineering-geological conditions of coal fields]. Tomsk, Tomsk State University Publ. house, 1992. Vol. 1, $288 \mathrm{p}$.
5. Olhovatenko V.E. Inzhenernaya geologiya ugolnykh mestorozhdeniy Sibiri i Dalnego Vostoka. Inzhenerno-geologicheskaya tipizatsiya ugolnykh mestorozhdeniy i otsenka ustoychivosti bortov karerov [Engineering Geology of coal deposits of Siberia and the Far East. Engineering-geological typification of coal deposits and evaluation of stability of pit walls]. Tomsk, Tomsk State University Publ. house, 1992. Vol. 2, 258 p.

6. Nifantov F.P., Pulyaev V.N. Voprosy metodiki inzhenerno-geologicheskikh issledovaniy burougolnykh issledovaniy Sibiri na stadii predvaritelnoy razvedki [Issues of methodology of engineering-geological investigations of the lignite research of Siberia at the stage of preliminary investigation]. Inzhenerno-geologicheskie usloviya stroitelstva krupnykh karerov $v$ Sibiri [Engineering-geological conditions for the construction of large open pit mines in Siberia]. Tomsk, Tomsk State University Publ. house, 1973. $260 \mathrm{p}$.

7. Olkhovatenko V.E., Trofimova G.I. Inzhenerno-geologicheskie usloviya razraboki otkrytym sposobom ugolnykh mestorozhdeniy Erunakovskogo rayona Kuzbassa i otsenka sostoyaniya okruzhayushchey sredy [Engineering-geological conditions of development of the open method of coal deposits Erunakovsky area of Kuzbas and assessment of the environment]. Tomsk, Tomsk State Univer- 
sity of Architecture and Building Publ. house, 2011. $204 \mathrm{p}$.

8. Shherbak G.G. Zakonomernosti formirovaniya inzhenerno-geologicheskikh usloviy ugolnykh mestorozhdeniy Vostochnoy Sibiri i ikh vliyanie na ustoychivost bortov karerov. Avtoreferat Dokt. nauk [Regularities of formation of engineering-geological conditions of coal deposits in Eastern Siberia and their impact on the stability of the sides of the quarries. Dr. Diss. Abstract]. Tomsk, 2003. $55 \mathrm{p}$.

9. Ganova S.D. Geoecological aspects of creation and functioning of natural and technical systems in the conditions of the cryolithozone of Western Siberia. Proc. of higher educational institutions. Geology and exploration, 2017, no. 5, pp. 58-64.

10. Zhang M.S., Dong Y., Du R.J., Gu X.F. Influence of coal mining on groundwater resources and countermeasures in Shanbei energy and chemical base. Earth Science Frontiers, 2010, vol. 17 (6), pp. 235-246.

11. Qiao W., Li W.P., Li T., Chang J.Y., Wang Q. Effects of coal mining on shallow water resources in semiarid regions: a case study in the Shennan mining area, Shaanxi, China. Mine Water Environment, 2017, vol. 36 (1), pp. 104-113.

12. Wang K., Lin Z.B., Zhang R.D. Impact of phosphate mining and separation of mined materials on the hydrology and water environment of the Huangbai River basin, China. Science of the Total Environment, 2016, vol. 543, pp. 347-356.

13. Jia W.W., Bao G.D., Wu X.W., Jiang S.W., Zhai C. Research and development of the mine geological environment evaluation system. Advanced Materials Research, 2011, vol. 270, pp. 1354-1359.

14. Marschalko M., Yilmaz I., Bednárik M., Kubečka K. Variations in the building site categories in the underground mining region of Doubrava (Czech Republic) for land use planning. Engineering Geology, 2011, vol. 122, pp. 169-178.

15. Ullah K.M., Mansourian A. Evaluation of land suitability for urban land-use planning: Case study Dhaka city. Transactions in GIS, 2016, vol. 20 (1), pp. 20-37.

16. Martínez-Graña A.M., Goy J.L., Zazo C. Engineering geology maps for planning and manegement of natural parks: «Las Batuecas-Sierra de Francia» and "Quilamas», (Central Spanish System, Salamanca, Spain). Geosciences, 2013, vol. 1, pp. 46-62.

17. Grib N.N., Kuznetsov P.Yu. Prediction of physical and mechanical properties of coal-bearing rocks on the basis of well logging data and mathematical apparatus of Markov nonlinear statistics. Ugol (Russian Coal Journal), 2018, no. 1, pp. 68-73.

18. Skomoroshko Yu.N. Otsenka ustoychivosti gornykh porod $v$ bortakh karerov po rezultatam geofizicheskikh issledovaniy skvazhin (na primere Elginskogo mestorozhdeniya). Dis. Kand. nauk [Evaluation of rock stability in the sides of the quarries on the basis of geophysical studies of wells (on the example of Elgin field). Cand. Diss.]. Neryungri, 2001. $181 \mathrm{p}$.

19. Khoyutanov E.A. Obosnovanie rezervov sovershenstvovaniya protsessov upravleniya zolnostyu uglya pri razrabotke slozhnostrukturnykh mestorozhdeniy (na primere Elginskogo mestorozhdeniya). Dis. Kand. nauk [Substantiation of reserves of improving the management of coal ash in development of complex fields (on the example of Elga Deposit)]. Cand. Diss.]. Yakutsk, $2016.155 \mathrm{p}$.

20. Berdyugin V.A. Conditions of mining of the Elginsky coal deposit and planned complexes of equipment for its development. Mining information Bulletin, 2009, vol. 10, pp. 373-379.

21. Nikolaeva N.A., Pinigin D.D. Assessment of factors of technogenic impact on the natural environment of the Elginsky coal complex. Modern problems of science and education, 2014, no. 5; Available at: www.science-education.ru/119-14545 (accessed: 05 November 2018).

22. Trofimov V.T., Krasilova N.S. Inzhenerno-geologicheskie karty [Engineering-geological maps]. Moscow, KDU, Dobrosvet Publ., 2018. $383 \mathrm{p}$.

23. Strokova L.A., Ermolaeva A.V. Zoning according to the hazard level of earth surface subsidence when designing the main gas pipeline in south Yakutia. Bulletin of the Tomsk Polytechnic University. Geo Assets Engineering, 2016, vol. 327, no. 10, pp. 59-68. In Rus.

24. Strokova L.A. Modeling of tunneling-induced ground surface movement. IOP Conf. Series: Earth and Environmental Science, 2015, vol. 24, 012030, 6 p.

25. Strokova L.A., Teterin E.A. Identification, diagnosis and ranking of risks of geohazard in pipeline and urbanized territories. IOP Conference Series: Earth and Environmental Science, 2016, vol. 43, 012051, $6 \mathrm{p}$.

26. Purgina D.V., Strokova L.A., Kuzevanov K.I. Modeling of changing hydrogeological conditions during construction of pier foundations on the Kama river bank. IOP Conference Series: Earth and Environmental Science, 2016, vol. 33, 01246, 6 p.

27. Cheskidov V.V., Manevich A.I. Engineering and geological support for slope stability monitoring as a part of transport infrastructure construction projects. Mining science and technology, 2016, no. 1, pp. 50-57.

28. Radkov A.V., Molchanov A.V., Terekhov A.V., Belenko E.V. Gosudarstvennaya geologicheskaya karta Rossiyskoy Federatsii. Masshtab 1:1000000 (trete pokolenie). Seriya Aldano-Zabaykalskaya. List 0-52 - Tommot. [The state geological map of the Russian Federation. Scale 1:1000000 (third generation). Series Aldano-Zabaikalskaya. Sheet 0-52-Tommot. Explanatory note]. St-Petersburg, Map factory VSEGEI, 2016. 276 p.

29. Osmushkin A.V., Osmushkina N.V. Otchet ob inzhenerno-geologicheskikh izyskaniyakh na obekte: «Proekt vskrytiya uchastka pervoocherednoy otrabotki Elginskogo mestorozhdeniya v predelakh Severo-zapadnogo uchastka» [Report on engineering-geological surveys at the facility: "The project of opening the site of priority mining Elga field within the North-Western area»]. Neryungri, 2009. $164 \mathrm{p}$.

30. Osmushkin A.V., Osmushkina N.V. Otchet ob inzhenerno-geologicheskikh izyskaniyakh na obekte «Elginsky gorno-obogatitalny kompleks. I cohered stroitelstvaa» na stadia proektnaya dokumentatsiya [Report on production of engineering-geological surveys at the facility: «Elga mining and processing complex. ${ }^{\text {st }}$ stage of construction». The stage of Project Documentation]. Neryungri, 2010. $1314 \mathrm{p}$.

Received: 10 December 2018.

\section{Information about the authors}

Lyudmila A. Strokova, Dr. Sc., professor, National Research Tomsk Polytechnic University.

Sofia A. Dmitrieva, postgraduate student, National Research Tomsk Polytechnic University.

Natalia V. Osmushkina, general director, Neryungristroyizyskaniya.

Andrey V. Osmushkin, chief engineer, Neryungristroyizyskaniya. 